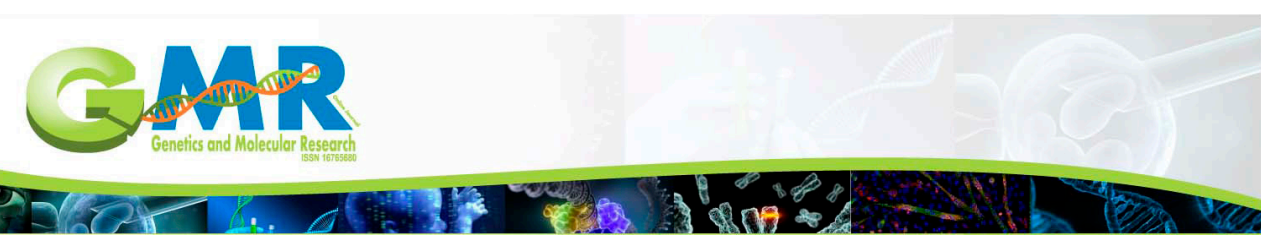

$\underline{\text { Retraction }}$

\title{
RETRACTION of two articles with plagiarism in common
}

Genet. Mol. Res. 15 (4): gmr.1504004

Published October 7, 2016

DOI http://dx.doi.org/10.4238/gmr.1504004

Copyright (C) 2016 The Authors. This is an open-access article distributed under the terms of the Creative Commons Attribution ShareAlike (CC BY-SA) 4.0 License.

The GMR editorial staff was alerted about two manuscripts that were found to be substantially equal. The Publisher and Editor decided to retract these articles in accordance with the recommendations of the Committee on Publication Ethics (COPE). After a thorough investigation, there is strong reason to believe that the peer review process was failure and, after review and contacting the authors, the editors of Genetics and Molecular Research decided to retract the article. The authors and their institutions were advised of this serious breach of ethics.

The retracted articles are:

Li Q, Chen C-F, Wang D-Y, Lü Y-T, et al. (2015). Transplantation of umbilical cord blood mononuclear cells increases levels of nerve growth factor in the cerebrospinal fluid of patients with autism. Genet. Mol. Res. 14: 8725-8732.

\section{Link to original paper}

and

Li Q, Chen C-F, Wang D-Y, Lü Y-T, et al. (2016). Changes in growth factor levels in the cerebrospinal fluid of autism patients after transplantation of human umbilical cord blood mononuclear cells and umbilical cord-derived mesenchymal stem cells. Genet. Mol. Res. 15: gmr.15027526.

\section{Link to original paper}

Genetics and Molecular Research 15 (4): gmr.1504004 
There is large-scale duplication of text from a previous publication by the authors in all sections of the articles and the Material and Methods section is identical for both manuscripts Li et al. (2015) and Li et al. (2016).

Other major study, from where the text has been copied substantially, was found and can be accessed at https:/translational-medicine.biomedcentral.com/ articles/10.1186/1479-5876-11-196. 